\title{
The resettlement of Armenians to the Azerbaijani territories and their attempts to seize those territories
}

УДК 94(479.24)

DOI https://doi.org/

10.24195/2414-9616-2018-4-85-87

Hasanova Ema Mehrab

Doctoral Student

of Azerbaijan State Pedagogical University

Uzeir Hajibeyov str., 68, Baku, Azerbaijan

\begin{abstract}
The article refers to the relocation of Armenians to Azerbaijan, the Russians' cooperation with the Armenians and the Christianization policy. As it is written in the article the historical purpose of Armenians was to establish a separate Armenian state at the expence of the Muslim lands with the help of Russia.As a result of the relocation of Armenians to Northern Azerbaijan, terrorist activities of Armenians and the protest of local population against it are listed with facts. Facts in the article prove that the Armenians in Northern Azerbaijan had high authority in various state bodies. The Armenians held the highest positions in the socio-political and other spheres. All these facts reveal the roots of today's "Karabakh" problem.

Key words: Azerbaijan, resettlement, Armenians, historical purpose, Russian-Turkish wars, Russian-Iranian wars, Irevan, Karabakh, Treaty of Adrianople, Turkmenchay and others.
\end{abstract}

The historical purpose of the Armenians was to establish a separate Armenian state at the expense of the Muslim lands with the help of Russia. The history of friendship between Armenians and Russians goes back many centuries ago. Preparations for the attack on Irevan during the II Russian-Iranian war, as well as the activities of Armenians during the Russian-Turkish wars were thoroughly planned by Armenian politicians. They had prepared a special regulation for organizing Armenians in this case. According to this regulation, 800 persons aged $18-30$ had tobe enrolled in Armenian volunteer squads. These volunteers were supplied with Russian arms. During the military service, Armenian soldiers were exempted from taxes and other duties. The first volunteer groups were set up in Tbilisi. Armenian young people were voluntarily enrolled in these groups. They had also created a separate cavalry regiment.

By 1823 , the total number of Armenians which were resettled by Russian empire to Karabakh had increased to 4366 families. The Armenians were given one year to passunder the Russian patronage according to the Treaty of Adrianople (Article 13), signed with Ottoman Empire and the treaty of Turkmenchay (Articles 14 and 15), signed with Iran. They could take all their belongings by themselves. It was assigned five years for carrying sizable items. The first official resettlement of Armenians took place on June 18, 1828. General I. Paskevich appointed colonel Y. Lazarev which was originally Armenian, to lead the resettlement. He immediately started this work (after the treaty of Turkmenchay) and sent a report to general Paskevich on February 14th. He wrote in this report, "Armenians did what they could in the war, and now they want to move to the Russian Empire. For the fast and convenient resettlement of Armenians, these measures must be taken: 1 ) to provide him with a document of appointment to lead the resettlement, 2) to authorize him appointing officers speaking Armenian language for resettlement and assistance, 3) to get the assistance of the army during difficulties arising from climatic and other conditions, 4) to provide financial support to the poor Armenian familie"

The Treaty of Turkmenchay seriously damaged Azerbaijan's economic life, at the same time led to a decline in the number of the population and increased the Armenian-Russian flow to the country, brought suffer to the local population leading to their desolation. According to estimates until 1897, almost 2 million Armenians were resettled to the South Caucasus, mainly to the territories where the Azerbaijanis lived. The process of resettlement of Armenians from Turkey and Iran to the South Caucasus was actively continued.

Despite of regular resettlement of Armenians to the Caucasus, especially to the territory of present Armenia, the number of Azerbaijanis always dominated here. For example, in 1886 only 81 of the 326 villages in the Zangezur territory were Armenian villages. The $66 \%$ of the population were Azerbaijanis and 34\% were Armenians in Irevan territory. Armenians committed crimes, terrorism, and genocide against Azerbaijanis in theseterritories. Armenian gangs created by Russians were famousfor their cruelty against the local population. The illusion "Great Armenia" was exactly the biggest reason for Armenians to commit terror and genocide.

The Russian support to Armenianshas its reasons. First, Armenians who constituted a part of the Christian population of the Muslim East lived mainly in the territories of Iran and especially of the Ottoman Empire, the main rivals of the Russian Empire in the Caucasus. Secondly, Armenians could be useful for Russia in the fight against those states in the future 
because they were aware of the weaknesses and strengths of Iran and Ottoman Empire. Thirdly, Armenians were always ready to follow any orders expecting benefits from it. Fourthly, the slogan of Armenians was: "The place where I can find bread is my homeland". Fifthly, they have never had their statehood.

The Russian researcher N.I. Shavrov noted the importance of the South Caucasus, especially of Azerbaijan for Russia and its economy. He also pointed out that the Caucasus railway was necessary for the export of Russian goods to Iran, India and other countries through the Black Sea, the Caspian Sea and the Mediterranean Sea. In addition, the author underlined the importance of the Caspian Sea for Russia considering Baku a successful key in the trade with the Caucasus and Iran.

It should be noted that not only Russians, but also European states were closely interested with the resettled Armenians. They also carried out missionary activity in the region and cooperated with Armenians. In particular, the Swiss Basel missionary society continued the Christianization policy in the regions under the Russian rule. Tsar Alexander supported the missionaries and was closely interested in them.

The missionaries were settled in the Caucasus in the places which they considered fit. In September 1823, they decided to make the city of Shushaas a center and all their goal were against local Muslim population. In addition, the missionaries visited Shamakhi and Baku and gathered supporters among Armenians.

As a result of Russians' strong propaganda, the number of Armenians willing to accept Russia's patronage has increased. After the Treaty of Turkmenchay, the Nakhchivan and Irevan khanates were annulled by the decree of Tsar I Nicolay on March 21 and was called "Armenian province". The head of the "Armenian province" was appointed D.O. Bebutov. During his tenure in 1830-38, he did much to resettle Armenians, improve their financial conditions, and helped them be represented in the executive bodies. As a result, the number of Armenians increased in the occupied territories, and they held important positions in the government bodies. In 1826-1832 the number of Armenians in the territories of Irevan and Nakhchivan increased by 3.5 times. The Armenian politicians intending to create an Armenian state, proposed to include other Azerbaijani lands, including the Sheki and Shamakhi khanates, into the Armenian province. It can be noted that in the occupation of South Caucasus the Armenians were particularly active. During the Russian-Turkish war most of the positions of commander in the Caucasus army were held by Armenians. All the industry and economy of the province, all leading positions, even in the fields of education and press were held by Armenians.

The Russians gave different promises to the Armenians and tried to seduce them in various ways. So they were exempt from taxes while doing business.
Using the tsarist colonial policy, the Armenians purchased Muslim lands by different means. For example, an Armenian called Sarkis Taryanyan, who lived in Shusha, bought a large land plot in Daralayaz and was exploiting the villagers living in these lands. Even Armenian merchants had a role in establishing market prices for grain in Azerbaijan.

Armenian capitalists had entered the silk industry in Azerbaijan too. They also had great advantages in the oil industry. Even in Baku, there were more Armenians than the Russians in the oil industry. Armenian capitalists cooperated with Russian capitalists and were very active in the transportation of Russian goods. On one hand, they got huge benefits and on the other hand strengthened their ties with Russia at the expense of the Azerbaijani resources. In the 70's of the 19th century, 37 percent of 46 oil plants in and around Baku belonged to Armenians. These plants were headed by 17 Armenian owners. It should be noted that in this period, Russian and foreign capitalists had only 79 oil wells in Baku. The number of Armenian entrepreneurs in Azerbaijan's industrial spheres was increasing. The expansion of the activity of Armenian capitalists created favorable conditions to implement their insidious plans in the future. Armenian politicians backed by Armenian entrepreneurs who were active in almost all spheres of the economy, were encouraging Armenians to occupy Muslim lands in different regions of Azerbaijan.

One of the main reasons for Armenians' achievement in different fields in Azerbaijan was the support of Russians. Thanks to the full support of Russians, Armenians achieved their intention by various means. The Armenians spread throughout the Russian Empire.

In the book «People are like that. The events of 1918-22 in the memoirs of an Armenian» by Ramstell De Hartwell is noted: "My name is Ovanes Apresian. I was born in Khankendi, in Shusha region of Azerbaijan in 1892. The population of these places consists of Turks and Armenians. In fact, this land historically belong to the Turks, Armenians were resettled. We lived as a Christian minority among Muslim Turks, who constitutes a majority of the population. From the childhood I was taught that what was bad for me was in connection of the name of Turks. The Russian books and newspapers I read repeated these words and the Russian writers were talking about the Turks' horror. Despite all this, I always loved Turks who worked with us. The first war and genocide experience we achieved in 1905. In the conversations with our family members, in the meetings we started to decrease the topics about the anti-Russian movement, and instead, the conversations about the hostility between Turks and Armenians began to increase. The Russians were able to turn the rebellion against them into the hostility between nations. Our people pushed the doors of Turkish houses, but they did not get any answers. They broke the doors and started a genocide that lasted until the last Turk was killed. 
In the morning we saw that the work was finished. I saw Shusha again later. There was nothing but stones in the Turkish neighborhoods of the city. All the houses were burned, and their owners were killed. The same thing happened to the Turkish neighborhoods in Khankendi. During the Armenian-Turkish war in 1905 we Armenians fought better. Most of us were experienced and trained in the Russian army".

The beginning of the Russian-Turkish war in 1877 helped Armenian politicians to be more active. A lot of volunteers from Echmiadzin, Aleksandropol, Akhalsikh, Karabakh, Tbilisi, Ganja and Baku were sent to the front. The vast majority of $\mathbf{4 2 . 0 0 0}$ volunteers were Armenians. Even in 1877, Armenian voluntary troops led by TerGukasov, general of the Irevan division of the Russian army, had occupied the city of Bayazid in Turkey.

The Armenians started to commit bloody acts also in the South Caucasus besides the Ottoman Empire. This led to collisions. On January 5 of 1887 , a collision took place between the Azerbaijanis and the Armenians in the Bazar square in Irevan. The incident had several reasons: the Armenians had killed two Azerbaijanis. The Azerbaijanis also killed two Armenians in response by self-defending. Many Armenians and Azerbaijanis gathered at the place where the incident had happened. 17 people were killed and wounded during the shootout. In fact, the incident happened in the Irevan Bazar square was a response to the Armenians' getting rich at the expense of the Azerbaijanis and their arrogance toward them, as it was written in the tsarist documents. In connection with this incident, the Irevan governor wrote in his confidential summary on May 5, 1885:

"Armenians gathering in the squares and streets began to shout slogans against Tatars. They attacked the Tatars one by one and fired at them in the back. In this attack the one third of Tatars were injured. Unlike the Armenians, the Tatars tried to avoid the conflict. They were in their mosques, not in the streets and squares. This abnormal relationship between the two nations can be dangerous and lead to serious results in the future. The Armenians seize Tatars' lands and trade" [3, p. 39-40].
So, the Armenians systematically resettled to the Azerbaijani territories from the beginning of the $X X$ century began to seize these lands with the help of the Russian Empire. And this increased the number of massacres committed by Armenians against local Muslim population.

\section{ЛITЕРАТУРA:}

1. Bilal N. Şimşir. British Documentation on Ottoman Armenians / volume I (1856-80), 769 p.; volume II (1880-90) 751 p. Türk Tarih Kurumu. Printing office. Ankara, 1989.

2. Freigl E. Amyth of terror: Armenian extremism, its causes and its historical context. EditionZEITGESCHICHTE-FREILASSING-SALZBURG. Printed in Austria. $143 \mathrm{p}$.

3. Qasımlı Musa. "Erməni məsələsi"ndən "erməni soyqırımı"na: gerçək tarix axtarışında (1724-1920). Bakı: Mütərcim, 2014, 462 s.

4. Marjanlı Musa. Armenians, Russia, the Caucasus. Khazar University press, 2011. 77 p.

5. Мехтиев Р. Нагорный Карабах: история, прочитанная по источникам. Москва: Аквариус, 2014. $280 \mathrm{c}$.

6. URL: 1905.az.

\section{REFERENCES}

1. Bilal N. Şimşir. British Documentation on Ottoman Armenians / volume I (1856-80), 769 p.; volume II (1880-90) 751 p. Türk Tarih Kurumu. Printing office. Ankara, 1989.

2. Freigl E. Amyth of terror: Armenian extremism, its causes and its historical context. EditionZEITGESCHICHTE-FREILASSING-SALZBURG. Printed in Austria. 143 p.

3. Gasimli Musa. "Ermeni meselesi"nden "ermeni soygirimi"na: gerchek tarikh akhtarishinda (1724-1920). Baki: Müterjim, 2014. 462 s.

4. Marjanlı Musa. Armenians, Russia, the Caucasus. Khazar University press, 2011. 77 p.

5. Mekhtiyev R. Nagorniy Karabakh: istoriya, prochitannaya po istochnikam. Moskva: Akvarius, 2014. $280 \mathrm{~s}$.

6. URL: 1905.az.

\section{Розселення вірмен на азербайджанські території та їх спроби захопити ці території}

Гасанова Ема Мехраб гизи

докторант

Азербайджанського державного педаго-

гічного університету

вул. Узеір Гаджибекова, 68, м. Баку,

Азербайджанська Республіка

\begin{abstract}
У статmі йдеться про переселення вірмен в Азербайджан, співпрацю росіян із вірменами та політику християнізації. Як написано в статmі, історичною метою армій було створення окремої вірменської держави за рахунок мусульманських земель за допомогою Росії. Внаслідок переселення вірмен у Північний Азербайджан, терористична діяльність вірмен та протест місцевого населення проти нього перераховані $з$ фактами. Факти в чій статті доводять, що вірмени в Північному Азербайджані мали високі повноваження в різних державних органах. Вірмени обіймали найвищі посади в суспільно-політичній та інших сфрерах. Усі ці фракти показують коріння нинішньоі «карабахської» проблеми.

Ключові слова: Азербайджан, переселення, вірмени, історичне призначення, російсько-турецькі війни, російсько-іранські війни, Ірлан, Карабах, Адріанопольський договір, Туркменія та ін.
\end{abstract}

